\title{
Detection of specific IgG and IgM antibodies to Toxoplasma gondii with a commercially available enzyme immunoassay kit system
}

\author{
ALAN H BALFOUR, JOHN P HARFORD \\ From the Toxoplasmosis Unit, Public Health Laboratory, Leeds
}

SUMMARY A total of 138 serum samples submitted for toxoplasma serology have been examined by enzyme immunoassay using kits produced by Labsystems Oy for the detection of specific antibodies of the IgG and IgM class. Results were compared with the dye test, an indirect haemagglutination test, and an indirect immunofluorescence test for specific IgM. The enzyme immunoassay was less sensitive than the dye test, but by running both IgG and IgM enzyme immunoassays, $92.4 \%$ sensitivity was achieved. The specificity of the enzyme immunoassay was good, with only one dye test negative serum giving a positive (but weak) IgG enzyme immunoassay reaction. Thirty serum samples from patients with no evidence of exposure to Toxoplasma gondii gave negative results in the IgM enzyme immunoassay.

Enzyme immunoassay results were expressed in enzyme immunoassay units, as a percentage value of a standard serum. This convention will be of value in the direct comparison of assay systems and in the application of quality control procedures.

The micro dye test ${ }^{12}$ is the definitive test in the serodiagnosis of infections due to Toxoplasma gondii. The need for live parasites maintained by animal passage and suitable human serum as a source of complement severely limits the availability of the dye test and has led to a continuing search for a practical alternative.

The indirect haemagglutination test, which uses a soluble antigen, is not a viable alternative, but it does provide further information on the probable stage of infection. ${ }^{3}$ Further and more useful information is provided by measuring concentrations of specific IgM using the indirect immunofluorescence test. ${ }^{4}$ Problems of false negative results due to competition by specific IgG and false positive results due to autoantibodies or rheumatoid factors necessitate separation of the IgG and IgM serum fractions before testing. This is a time consuming and labour intensive process, even though microprocedures have been developed. ${ }^{5}$

Many enzyme linked immunoabsorbent assays have been developed for the detection of specific antibodies to $T$ gondii. ${ }^{6}$ We have compared the IgG

Accepted for publication 22 January 1985 and IgM enzyme immunoassay kit from a commercial supplier with our standard test system, the dye test, an indirect haemagglutination test, and an indirect immunofluorescence test for specific IgM.

\section{Material and methods}

Human serum samples routinely submitted from suspected cases of toxoplasmosis were used for this study; they were selected to cover the full range of dye test titres. Samples with a minimum volume of $300 \mu \mathrm{l}$ and a shorter storage time were used in preference. Samples were stored at $-20^{\circ} \mathrm{C}$ until required. Thirty six samples from 15 patients from whom more than one specimen had been submitted were also investigated.

\section{DYE TEST}

The dye test was performed in flat bottomed microtitre plates and read directly using an inverted microscope, as described previously. ${ }^{.}$The test was standardised against the toxoplasma national control serum produced at the Public Health Laboratory, Tooting. The national control serum contains $1000 \mathrm{IU} / \mathrm{ml}$ by reference to the World Health Organisation dye test standard serum. 
INDIRECT HAEMAGGLUTINATION TEST

The indirect haemagglutination test was performed in microtitre plates with V-shaped wells using sensitised turkey cells.

INDIRECT IMMUNOFLUORESCENCE TEST FOR IgM The indirect immunofluorescence test was carried out as previously described ${ }^{4}$ using an antihumanIgM conjugate (Tago-TCS, Slough). Evans blue was incorporated as a counterstain at a final dilution of $1 / 10000$ (wt/vol). The slides were read using a dry $(\times 40)$ objective and $a(\times 10)$ binocular eyepiece on a Leitz Dialuz incident light microscope fitted with an HBO 50 mercury vapour lamp together with fluorescein isothiocyanate and rhodamine filter clusters. Using the rhodamine filter cluster parasites were readily detected by their brick-red appearance due to the Evans blue counterstain. Specific fluorescence was then readily monitored by switching to the fluorescein isothiocyanate cluster and looking for bright peripheral staining. The end point was taken as the last dilution showing more than half of the parasites with bright staining of the entire peripheral margin of the organism. Indirect immunofluorescence test titres were determined before and after fractionation. A positive serum of known titre established by exchange with the Toxoplasma Unit at the Public Health Laboratory, Tooting, was run with each batch of samples, together with an antigen control, a dye test negative serum; and a dye test positive serum, negative for specific IgM. Doubling dilutions of serum from $1 / 10$ to $1 / 320$ were run.

Titres in these three tests were expressed as the reciprocal of the end point dilution.

\section{SERUM FRACTIONATION}

Samples were fractioned by gel filtration on Bio-Gel A-5 m (200-400 mesh) (Bio-Rad Laboratories Ltd, Watford) using a modification of the method of Pyndiah et al. ${ }^{5}$ The gel was equilibrated with $50 \mathrm{mM}$ Tris buffer, $\mathrm{pH} 7 \cdot 2$, containing $150 \mathrm{mM}$ sodium chloride and $0.03 \%$ sodium azide and packed into disposable plastic columns (Uniscience Ltd, London SW18) giving a bed of $7 \times 50 \mathrm{~mm}$. A support disc was placed on top of the bed to aid sample loading and prevent drying out of the gel if left unattended during elution. Plastic disposal tubes (LP2/2 Luckams Ltd, Burgess Hill, West Sussex) were used to collect the eluate. These stood securely in the wells of a microtitre plate, providing a convenient rack system.

A $100 \mu$ l aliquot of serum was thoroughly mixed with $5 \mu$ l of dextran blue 2000 (Pharmacia, Milton Keynes) $(50 \mathrm{mg} / \mathrm{ml})$ and $50 \mu \mathrm{l}$ applied to the disc on top of the gel bed. The void volume of buffer was then applied, run through, and discarded. A further $300 \mu \mathrm{l}$ of buffer was applied and the corresponding eluate collected as the IgM fraction. Preliminary studies showed that this fraction, running just behind the blue dextran, contained $55-60 \%$ of the IgM in the original specimen and was essentially free of $\operatorname{IgG}$ and IgA. In subsequent assays this fraction was treated as a $1 / 10$ dilution of the original serum.

A positive serum with a known specific IgM titre was fractionated with each batch of tests and both the whole serum and fraction titrated in the indirect immunofluorescence test for $\operatorname{IgM}$. The run was discarded unless these two values were in close agreement.

\section{ENZYME IMMUNOASSAY TESTS}

Two $T$ gondii enzyme immunoassay test kits are produced, one specific for human IgG and the other for IgM (Labsystems Oy, Pulttitie 9-11, Helsinki 81 , Finland). Both use a nine channel cuvette block sensitised with a $T$ gondii antigen preparation. The kits contain 12 cuvette blocks ( 108 cuvettes) and all reagents for the assay except $0.9 \%$ saline needed for the washing steps and $1 \mathrm{M}$ sodium hydroxide needed to stop the enzyme reaction. The cuvettes are compatible with the Labsystems discrete multichannel analysis system. ${ }^{8}$ Multichannel Finnpipettes (nine channel) (Labsystems Oy) were used to transfer serum and reagents, standardising across the cuvette block. The cuvettes were incubated using the FP-400 incubator (Labsystem Oy) and the final absorbance values read using the FP-901 analyser, a semiautomatic nine channel photometer (Labsystems Oy).

IgG ENZYME IMMUNOASSA Y TEST

Initial serum dilutions at $1 / 200$ were set up in unsensitised cuvettes, using a Hamilton Microlab-M autodilutor (VA Howe and Co Ltd, London SW18) to pick up $2.5 \mu \mathrm{l}$ of serum and dispense this in a volume of $500 \mu \mathrm{l}$ with diluent buffer (phosphate buffered saline, $\mathrm{pH} 7 \cdot 4$, with $0.02 \%$ sodium azide) Aliquots of $200 \mu \mathrm{l}$ of serum were then transferred to the sensitised cuvettes held at $37^{\circ} \mathrm{C}$ on the incubator block, in duplicate, using the nine channel Finnpipette. The cuvettes were sealed and incubated for $90 \mathrm{~min}$. After emptying, the cuvettes were washed three times in $0.9 \%$ saline containing Tween 20 at $1 / 500$, using the nine channel pipette to transfer $400 \mu$ l volumes to each well. Alkaline phosphatase conjugated antihuman IgG, diluted $1 / 10$ with diluent buffer and equilibrated to $37^{\circ} \mathrm{C}$, was then rapidly added, $200 \mu \mathrm{l}$ per well. The sealed cuvettes were incubated at $37^{\circ} \mathrm{C}$ for $60 \mathrm{~min}$ and then washed as previously. The substrate solution contained one $5 \mathrm{mg}$ tablet of p-nitrophenyl phosphate in $2.5 \mathrm{ml}$ of 
$1.01 \mathrm{M}$ diethanolamine buffer with $0.505 \mathrm{mM}$ $\mathrm{MgCl}_{2}, \mathrm{pH} 10 \cdot 0$. This was prewarmed to $37^{\circ} \mathrm{C}$ and $200 \mu \mathrm{l}$ was added to each well of the cuvette block, followed by incubation at $37^{\circ} \mathrm{C}$ for $30 \mathrm{~min}$. The reaction was stopped by the simultaneous addition of $200 \mu \mathrm{l}$ of $1 \mathrm{M}$ sodium hydroxide to each well of the cuvette block. Absorbance values were read at $405 \mathrm{~nm}$ after blanking the photometer against distilled water.

Positive and negative control serum samples supplied freeze dried at the working dilution-that is, $1 / 200$ - were run with each batch of sera, together with a reagent blank, containing diluent instead of serum.

\section{IgM ENZYME IMMUNOASSAY TEST}

Initial serum dilutions of $1 / 100$ were set up in unsensitised cuvette blocks by picking up $5 \mu \mathrm{l}$ of test serum and delivering $500 \mu \mathrm{l}$ by means of the Microlab-M autodilutor, using phosphate buffered saline, $\mathrm{pH} 7.4$, with $0.05 \%$ sodium azide as preservative and $5 \%$ protein carrier solution to reduce non-specific reactions. Aliquots of $200 \mu \mathrm{l}$ of serum were transferred to the sensitised cuvettes and loaded on the incubator block at $37^{\circ} \mathrm{C}$ for $2 \mathrm{~h}$. Washing and all other procedures were the same as for the IgG assay, except that an antihuman IgM alkaline phosphate conjugate was used, with incubation for $2 \mathrm{~h}$ at $37^{\circ} \mathrm{C}$.

IgM positive and negative controls were supplied and run with each batch of test samples, together with a reagent blank containing no serum. In most cases samples were run in duplicate.

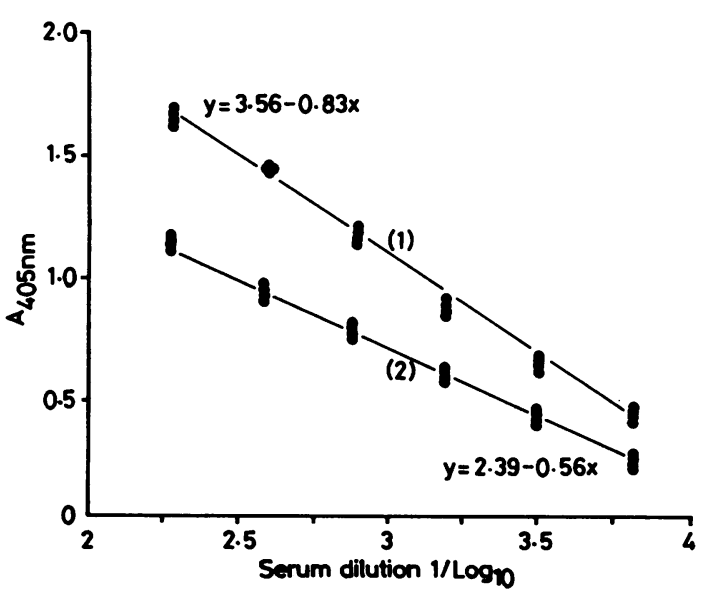

Fig. 1 Absorbance as a function of serum dilution for the (1) WHO and (2) national control serum dye test standard samples in the IgG enzyme immunoassay.
DETERMINATION OF ANTIBODY LEVELS BY ENZYME IMMUNOASSAY

Measurement of antibody concentrations in the serum samples was based on the use of positive and negative reference samples supplied with the kits. Antibody levels are expressed as arbitrary enzyme immunoassay units (EIU), which were calculated using the formula:

$$
\frac{\text { A405 sample }- \text { A405 blank }}{\text { A405 positive control - A405 blank }} \times 100
$$

where A405 is the absorbance at $405 \mathrm{~nm}$.

An IgG enzyme immunoassay value of $<10$ EIU was regarded as negative, 10-20 EIU as a doubtful positive, and $>20$ EIU as positive. In the IgM enzyme immunoassay $<20$ was considered negative, 20-40 EIU as a doubtful positive, and $>40$ EIU as positive.

\section{IgM CONFIRMATORY TEST}

All samples giving an IgM enzyme immunoassay result $\geqslant 20$ EIU were pretreated before retesting using the confirmatory test kit (Labsystems Oy) to remove serum factors which may otherwise give a false positive result. Ten microlitres of test serum was added to the pretreatment solution provided predispensed in stoppered plastic tubes. The stoppered tubes were then kept agitated at $37^{\circ} \mathrm{C}$ for $30 \mathrm{~min}$ and centrifuged for $10 \mathrm{~min}$ at about $1000 \mathrm{~g}$. A further $1 / 5$ dilution was made by carefully removing $100 \mu \mathrm{l}$ of supernatant and delivering this in a total volume of $500 \mu \mathrm{l}$ to the well of an unsensitised

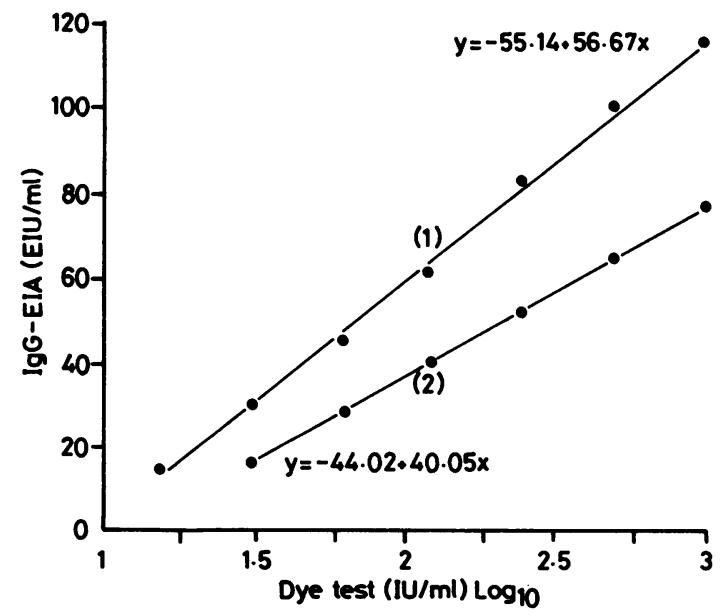

Fig. 2 Calibration of the IgG enzyme immunoassay (EIA) against the (1) WHO and (2) national control serum dye test standards. 
cuvette, using the IgM enzyme immunoassay diluent. The IgM enzyme immunoassay was then repeated as previously described.

\section{Results}

\section{CALIBRATION OF THE IgG SYSTEM}

Dilutions of both the WHO toxoplasma dye test control serum and the toxoplasma national control serum were run at six levels in the IgG enzyme immunoassay system and the dose response measured. Fig. 1 shows absorbance readings as a function of serum dilution. Up to six estimations were made at each level. Linear regression lines for each set of data were calculated by the method of least squares. The regression lines for the two standards were not parallel: the WHO serum showed a sharper response $(y=3.56-0.83 \times)$ compared with the national control serum $(y=2.39-0.56 \times)$. The correlation within each set of data was good, with a correlation coefficient of 0.99 . At the normal test dilution of $1 / 200$ the WHO standard showed a value of 113 EIU while the national control serum standard gave a value of $77 \mathrm{EIU}$, only $68 \%$ of the WHO value.

Fig. 2 shows a plot of mean absorbance against concentration for each of the two standards. In both cases the negative cut off value of $10 \mathrm{EIU}$ was out of range and the equivalent titre in international units could not be calculated. The positive cut off value of $20 \mathrm{EIU}$ gave $21 \mathrm{IU} / \mathrm{ml}$ with the WHO standard and $40 \mathrm{IU} / \mathrm{ml}$ with the national control serum standard, corresponding to dye test titres of 85 and 158 respectively. The low positive control serum supplied with the IgG enzyme immunoassay kit had a

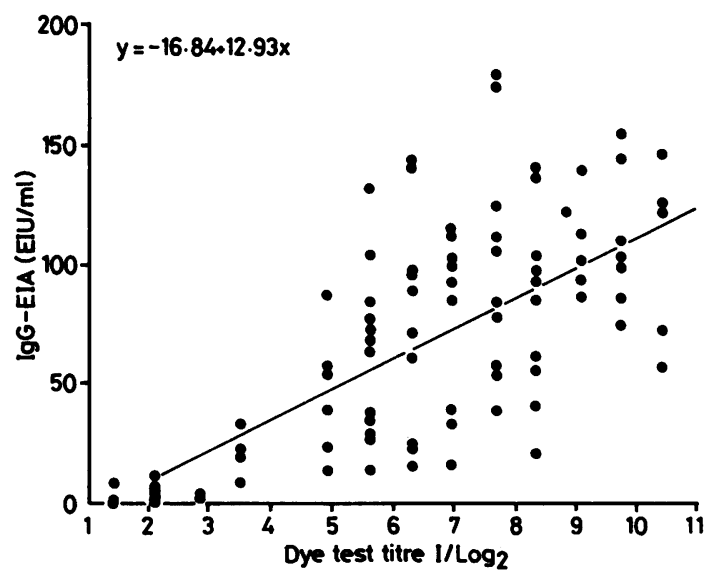

Fig. 3 Agreement of the IgG enzyme immunoassay (EIA) with the dye test, showing the linear regression futted to the data $(r=0.708)$. value of 62 EIU: $118 \mathrm{IU} / \mathrm{ml}$ against the WHO standard and $449 \mathrm{IU} / \mathrm{ml}$ against the national control serum, dye test titres of 470 and 1794 . The negative control serum supplied with the kit gave a value of 4 EIU and when tested directly in the dye test a value of $<2 \mathrm{IU} / \mathrm{ml}(<8)$.

Measured against the WHO standard the lowest detectable dye test titre would be $16 \mathrm{IU} / \mathrm{ml}(64)$, equivalent to $13 \mathrm{EIU}$. Against the national control serum the value would be $31 \mathrm{IU} / \mathrm{ml}$ (124), equivalent to $16 \mathrm{EIU}$. The IgG enzyme immunoassay is therefore somewhat less sensitive than the dye test in detecting low but significant concentrations of specific antibody.

COMPARISON OF THE DYE TEST AND IgG ENZYME IMMUNOASSAY

A total of 138 samples were tested in both the dye test and IgG enzyme immunoassay (Fig. 3). When dye test titres of $>\log _{2} 4(>16)$ and IgG enzyme immunoassay titres $>10$ ElU were taken as positive, paired readings on the samples showed a fair level of agreement, with $86 \%(119 / 138)$ positive in the dye test and $82 \%(113 / 138)$ positive in the IgG enzyme immunoassay. A total of $94 \%(130 / 138)$ of the samples gave consistent positive or negative results in both tests. Linear regression analysis by the least squares method gave a correlation coefficient of 0.708 ; the line was described by the equation $y=-16 \cdot 84+12.93 x$, giving a reasonable fit but a fair degree of scatter.

Five samples, classed as negative in the IgG enzyme immunoassay, had positive but relatively low dye test titres $\left(<\log _{2} 5(<32)\right)$. One of these samples gave a positive indirect immunofluores-

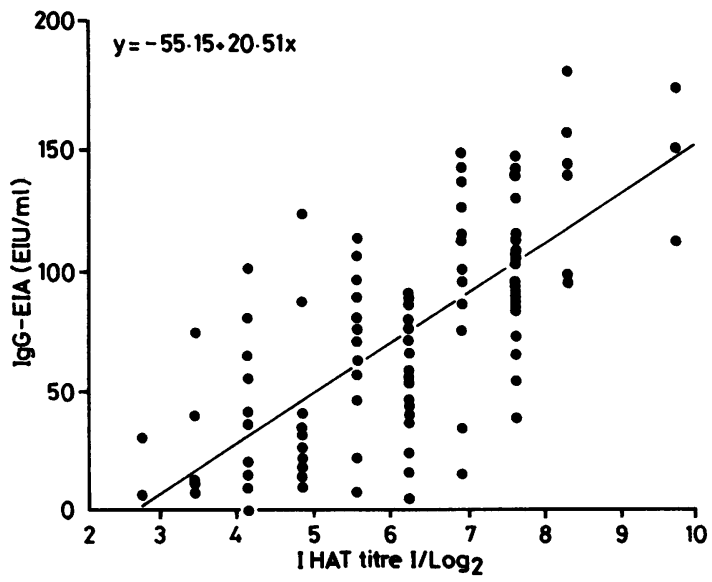

Fig. 4 Agreement of the IgG enzyme immunoassay (EIA) with the indirect haemagglutination test (IHAT), showing the linear regression fitted to the data $(r=0.784)$. 
cence test result after fractionation, but the overall serological pattern and clinical symptoms were not suggestive of a recent infection.

Two further samples, negative in the IgG enzyme immunoassay, had significant titres in the dye test of $\log _{2} 9(512)$ and were confirmed recent cases of toxoplasmosis. These samples were positive in both IgM systems. They would not have been detected by enzyme immunoassay if the recommended procedure of measuring IgM only on samples with $\mathrm{IgG}$ values of $>10$ EIU had been followed.

One serum had an IgG enzyme immunoassay value of $12 \mathrm{EIU}$, which by itself was of uncertain importance but taken with the negative IgM result this was indicative of an old infection. The dye test titre on this serum was $\log _{2} 3(8)$ but the indirect haemagglutination test value was slightly higher, at $\log _{2} 6(32)$.

Nine samples with significant dye test values fell into the uncertain zone on the $\mathrm{IgG}$ enzyme immunoassay scale (10-20 EIU). Of these, eight proved to be recent early cases of infection and gave positive results for specific IgM. The remaining serum was from a past infection, with dye test $\log _{2} 5$ (32), indirect haemagglutination test $\log _{2} 7$ (128), and indirect immunofluorescence test for IgM negative.

\section{COMPARISON OF INDIRECT}

HAEMAGGLUTINATION TEST AND IgG ENZYME IMMUNOASSAY

A titre of $\log _{2} 5$ (32) is regarded as significant in the indirect haemagglutination test. Paired readings on the samples showed fairly good agreement between the indirect haemagglutination test and IgG enzyme immunoassay (Fig. 4). Eighty eight percent (121/ 138) were positive in the indirect haemagglutination

Table 1 Comparison of the enzyme immuñoassay and indirect immunoftuorescence test assays for specific $1 \mathrm{gM}$, showing the level of agreement between the two systems

\begin{tabular}{|c|c|c|}
\hline Classification & No & $\%$ \\
\hline $\begin{array}{l}\text { Indirect immunofluorescence test } \\
\text { positive }(\geqslant 1 / 10) \text { whole sera }\end{array}$ & 57 & $51 \cdot 8$ \\
\hline $\begin{array}{l}\text { Indirect immunofiuorescence test } \\
\text { positive }(\geqslant 1 / 10) \text { fractionated sera }\end{array}$ & 77 & $70 \cdot 0$ \\
\hline $\begin{array}{l}\text { Enzyme immunoassay positive } \\
(\geqslant 40 \text { EIU })\end{array}$ & 36 & $32 \cdot 7$ \\
\hline $\begin{array}{l}\text { Enzyme immunoassay doubtful } \\
\text { positive ( } 20-40 \text { EIU) }\end{array}$ & 19 & $17 \cdot 3$ \\
\hline $\begin{array}{l}\text { Positive or negative in both enzyme } \\
\text { immuoassay and indirect } \\
\text { immunofluorescence test }\end{array}$ & & \\
\hline $\begin{array}{l}\text { Indirect immunofluorescence test } \\
\text { whole serum } \\
\text { Indirect immunofluorescence test }\end{array}$ & 63 & $53 \cdot 7$ \\
\hline fractionated serum & 69 & $62 \cdot 7$ \\
\hline
\end{tabular}

$\mathrm{n}=110$

Enzyme immunoassay values $<20$ EIU are negative. test, $82 \%(113 / 138)$ were positive in the $\operatorname{IgG}$ enzyme immunoassay, while $93 \%(128 / 138)$ gave consistent positive or negative results in both tests. In the indirect haemagglutination test positive and IgG enzyme immunoassay negative group $3 / 9$ (33\%) were IgM enzyme immunoassay positive, although the overall serological pattern and clinical information suggested that only one of these samples was from a probable recent infection. Linear regression analysis by the least square method gave a correlation coefficient of 0.784 , the line being described by the equation $y=-55 \cdot 2+$ $20.5 \mathrm{x}$. The correlation was slightly better than with the dye test, but again there was a large amount of scatter.

\section{COMPARISON BETWEEN THE INDIRECT}

IMMUNOFLUORESCENCE TEST IgM AND ENZYME IMMUNOASSAY IgM ASSAYS

A total of 110 routinely submitted samples were examined for IgM class antibodies by both the indirect immunofluorescence test and enzyme immunoassay systems. Assays in the indirect immunofluorescence test system were run on both the whole serum and the $\operatorname{IgG}$ depleted fraction obtained by passing the serum down a mini-column of Bio-Gel A-5 m as described.

Forty six samples were negative in the IgM enzyme immunoassay, with values $<20$ EIU. The remaining 64 samples, giving values $\geqslant 20 \mathrm{EIU}$, were adsorbed using the confirmatory kit and retested. The value after adsorption was used as the final IgM enzyme immunoassay result. The negative control serum supplied gave an average value of $5 \mathrm{EIU}$ in the IgM enzyme immunoassay. Predilution of both the positive and negative controls supplied in the enzyme immunoassay kit prevented indirect immunofluorescence test titres from being determined. The national control serum gave a strong positive result (91 EIU) in the IgM enzyme immunoassay, although only a weak reaction of $1 / 10$ in the indirect immunofluorescence test for IgM.

The distribution of the IgM enzyme immunoassay results on the whole serum and after adsorption of any sample with an initial titre of $\geqslant 20$ EIU has been plotted against the indirect immunofluorescence test for IgM titres on (a) whole serum and $(b)$ the fractionated serum after gel filtration. Geometric mean titres are also shown for each class of indirect immunofluorescence test titres (Figs. 5 and 6). These data are summarised in Table 1. Using the data obtained after adsorption for the IgM enzyme immunoassay, a total of $63 / 110$ sera $(53.7 \%)$ were either positive or negative in both the indirect immunofluorescence test and enzyme immunoassay when the former was carried out on whole serum. 


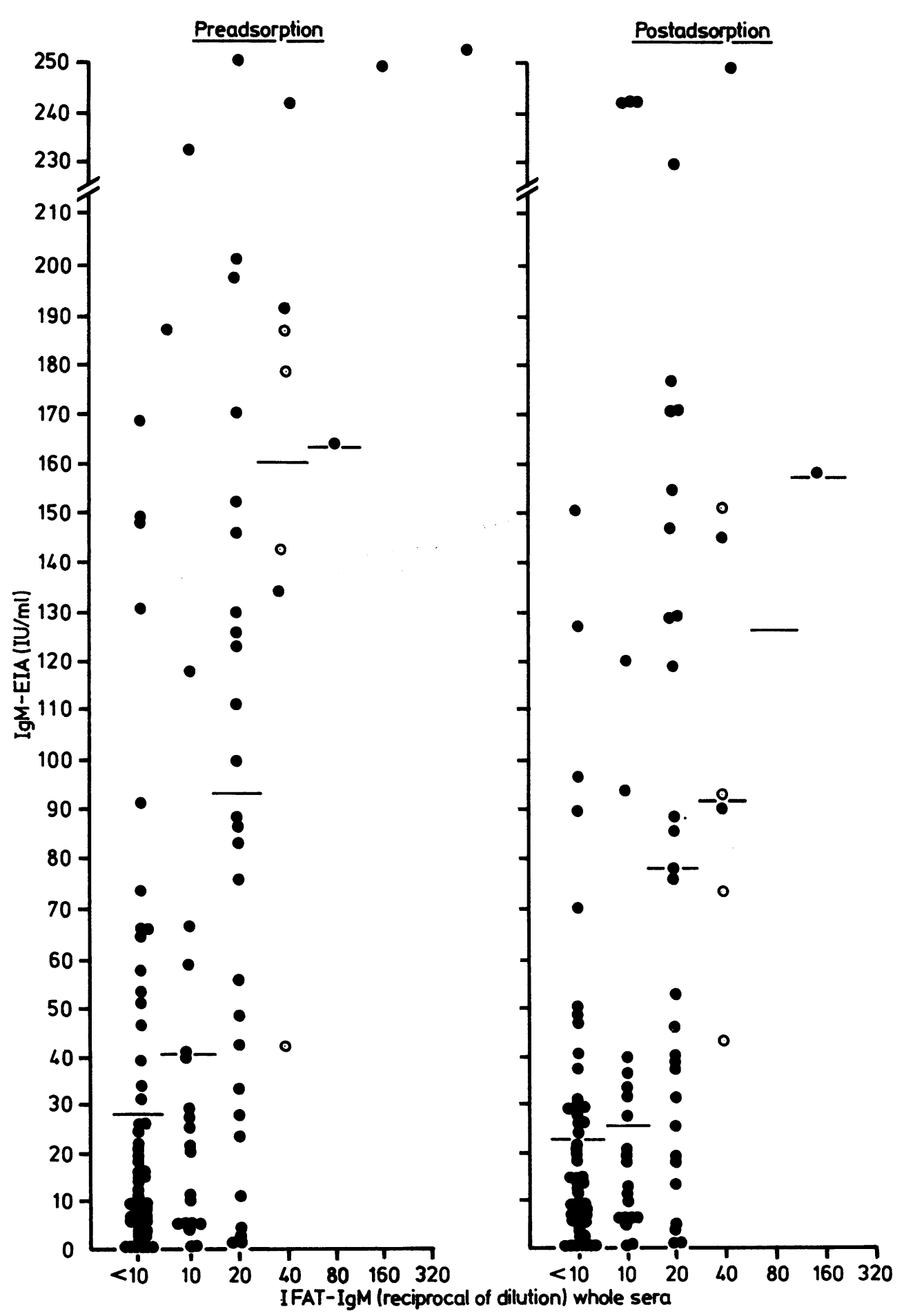

Fig. 5 Comparison of the IgM enzyme immunoassay (EIA) before and after adsorption, with the indirect immunofuorescence test (IFAT) for IgM performed on whole serum. The geometric mean titres are shown in each group by the bar. Values $>$ the plotted IFAT titre are shown as open circles. 
Detection of specific IgG and IgM antibodies to Toxoplasma gondii

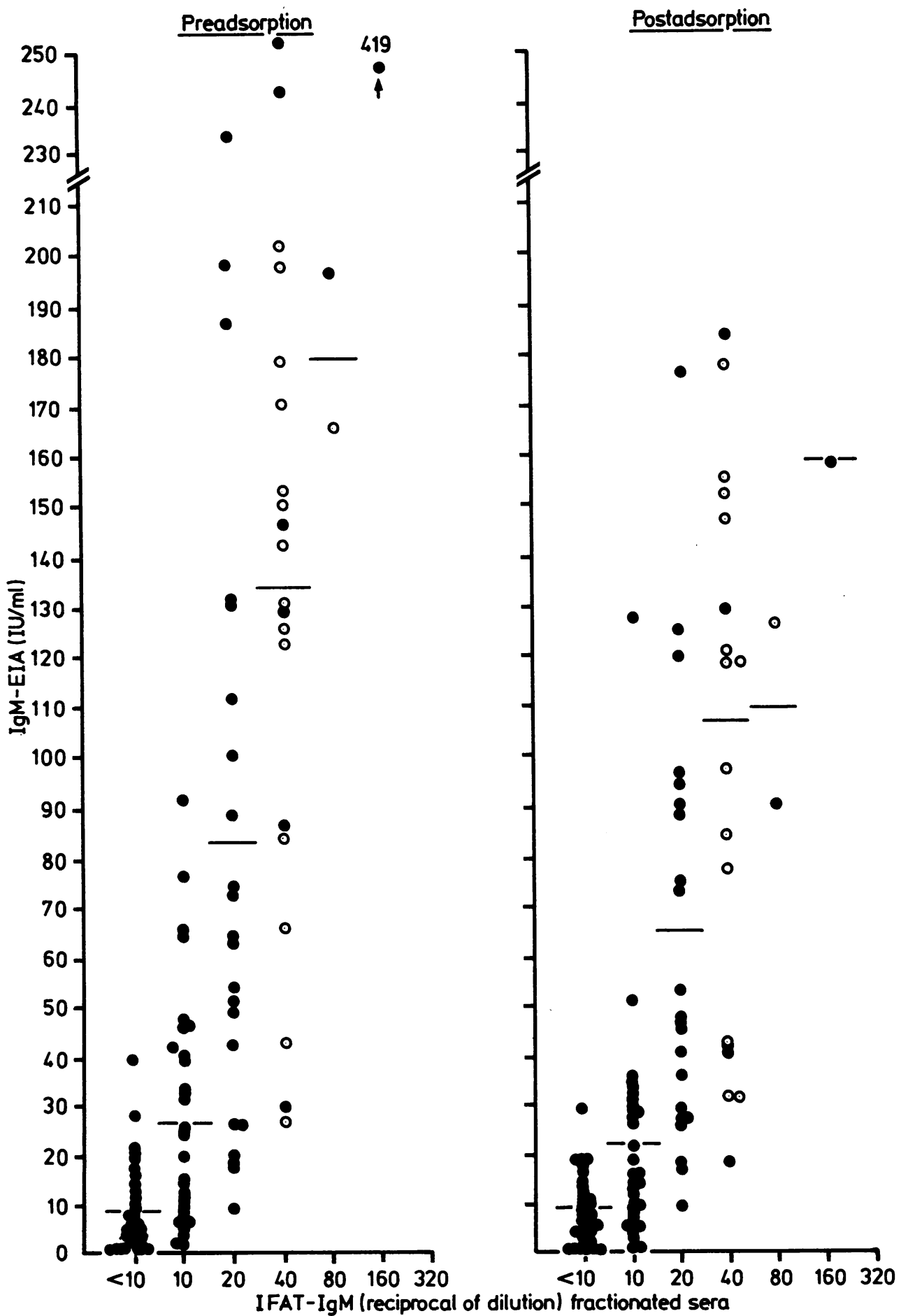

Fig. 6 Comparison of the IgM enzyme immunoassay (EIA) before and after adsorption, with the indirect immunofuorescence test (IFAT) for IgM performed on the fractionated serum. The geometric mean titres are shown in each group by the bar. Values $>$ the plotted IFAT titre are shown as open circles. 
This figure rose slightly to $69 / 110(62 \cdot 7 \%)$ when the IgM fraction was used. The indirect immunofluorescence test gave more IgM positive results, 77/110 $(70 \%)$, when used to test fractionated serum. This fell to $57 / 110(51.8 \%)$ with whole serum. Only $36 /$ $110(32.7 \%)$ of the samples were positive with the IgM enzyme immunoassay system.

\section{IgM ENZYME IMMUNOASSA Y SPECIFICITY}

To examine further the specificity of the IgM enzyme immunoassay test a total of 30 samples showing no evidence of exposure to $T$ gondii were re-examined by the IgM enzyme immunoassay test (dye test $<8$, indirect haemagglutination test $<32$, indirect immunofluorescence test $<10)$. No false positive results were found in the IgM enzyme immunoassay, all values were recorded at $<3$ EIU.

\section{SENSITIVITY OF THE ENZYME IMMUNOASSAY SYSTEM}

The dye test was taken as the definitive system in order to assess the relative sensitivity of the IgG enzyme immunoassay both alone and in combina- tion with the IgM enzyme immunoassay, where sensitivity is given by the expression:

Number of samples dye test positive + enzyme immunoassay positive $\times 100$ Total number of sera dye test positive

When only samples giving positive IgG enzyme immunoassay results were considered the sensitivity was $88.2 \%$ - that is, $105 / 119$-but this increased to $92.4 \%(110 / 119)$ if samples showing positive results in either the IgG or IgM enzyme immunoassay system were included.

SPECIFICITY OF THE IgG ENZYME IMMUNOASSA Y SYSTEM

The specificity was measured against the dye test using the expression:

Number of sera dye test negative $+\operatorname{IgG}$ enzyme immunoassay negative $\times 100$ Total number of sera dye test negative

A value of $94.7 \%(18 / 19)$ was obtained. The remaining serum had a dye test value of 8 and $\mathrm{IgG}$ enzyme immunoassay value of $12 \mathrm{EIU}$, values of doubtful significance. No IgM was detected.

Table 2 Sequential serum samples examined by the dye test, indirect haemagglutination test, and enzyme immunoassay $(\lg G, \lg M)$

\begin{tabular}{|c|c|c|c|c|c|c|c|}
\hline \multirow{2}{*}{$\begin{array}{l}\text { Patient } \\
\text { no }\end{array}$} & \multirow[t]{2}{*}{ Date } & \multirow[t]{2}{*}{ Dye test } & \multirow{2}{*}{$\begin{array}{l}\text { Indirect } \\
\text { haemagglutination } \\
\text { test }\end{array}$} & \multirow{2}{*}{$\begin{array}{l}\text { IgG enzyme } \\
\text { immunoassay }\end{array}$} & \multicolumn{2}{|c|}{ IgM enzyme immunoassay } & \multirow{2}{*}{$\begin{array}{l}\text { Symptoms/ } \\
\text { comments }\end{array}$} \\
\hline & & & & & Whole serum & Adsorbed & \\
\hline \multirow[t]{2}{*}{1} & 08.1 .82 & 4096 & 2048 & 105 & 130 & 176 & \multirow[t]{2}{*}{ Glands } \\
\hline & 18.5 .82 & 16384 & 512 & 70 & 100 & 89 & \\
\hline \multirow[t]{4}{*}{2} & 09.12 .81 & 1024 & 128 & 10 & 164 & 126 & \multirow{4}{*}{$\begin{array}{l}\text { Mother of } \\
\text { infected baby }\end{array}$} \\
\hline & 14.05 .82 & 8192 & 2048 & 113 & 27 & 38 & \\
\hline & 30.06 .82 & 4095 & 16384 & 147 & 26 & 32 & \\
\hline & 14.12 .82 & 2048 & 1024 & 124 & 21 & 32 & \\
\hline \multirow[t]{2}{*}{3} & 07.04 .82 & 256 & 512 & 14 & 198 & 171 & \multirow[t]{2}{*}{ Glands } \\
\hline & 04.05 .82 & 4096 & 64 & 41 & 123 & 78 & \\
\hline \multirow[t]{4}{*}{4} & 02.03 .82 & 4096 & 4096 & 97 & 38 & 21 & \multirow[t]{4}{*}{ Glands } \\
\hline & 30.03 .82 & 1024 & 2048 & 93 & 22 & 20 & \\
\hline & 28.04 .82 & 1024 & 2048 & 103 & 29 & 54 & \\
\hline & 07.07 .82 & 1024 & 2048 & 93 & 22 & 82 & \\
\hline \multirow[t]{2}{*}{5} & 17.12 .82 & 256 & 256 & 80 & 202 & 171 & \multirow[t]{2}{*}{ Glands } \\
\hline & 28.01 .83 & 8192 & 2048 & 140 & 132 & 97 & \\
\hline \multirow[t]{2}{*}{6} & 27.04.82 & 32768 & $>16384$ & 148 & 59 & 36 & \multirow[t]{2}{*}{ T cell lymphoma } \\
\hline & 27.07 .82 & 16384 & $>16384$ & 111 & 58 & 16 & \\
\hline \multirow[t]{2}{*}{7} & 16.12 .82 & 512 & 64 & 65 & 153 & 155 & \multirow[t]{2}{*}{ Glands } \\
\hline & 01.02 .83 & 8192 & 1024 & 103 & 67 & 70 & \\
\hline \multirow[t]{2}{*}{8} & 01.12 .77 & 32768 & 128 & 122 & 169 & 199 & \multirow[t]{2}{*}{ Glands } \\
\hline & 17.09 .81 & 512 & 4096 & 141 & 40 & 14 & \\
\hline \multirow[t]{2}{*}{9} & 29.12 .81 & 16384 & 256 & 112 & 176 & 73 & \multirow[t]{2}{*}{ Glands, malaise } \\
\hline & 11.11 .82 & 4096 & 4096 & 132 & 79 & 51 & \\
\hline \multirow[t]{2}{*}{10} & 09.09 .81 & 256 & 1024 & 73 & 43 & 16 & \\
\hline & 28.10 .81 & 4096 & 64 & 79 & 17 & - & $\begin{array}{l}\text { abdominal pains, } \\
\text { vomiting }\end{array}$ \\
\hline 11 & 14.10 .81 & 512 & 256 & 7 & 146 & 41 & Glands \\
\hline & 19.11 .81 & 4096 & 64 & 34 & 104 & 31 & \\
\hline 12 & 07.02 .80 & 512 & 128 & 17 & 419 & 158 & Glands \\
\hline & 03.03 .80 & 2048 & 512 & 39 & 417 & 187 & \\
\hline 13 & 16.01 .78 & 512 & 128 & 17 & 183 & 74 & Glands \\
\hline & 13.03 .78 & 32768 & 32 & 73 & 112 & 53 & \\
\hline 14 & 17.11 .81 & 16384 & 256 & 75 & 94 & 16 & Glands \\
\hline & 07.01 .82 & 8192 & 512 & 87 & 83 & 38 & \\
\hline & 05.04 .82 & 2048 & 256 & 54 & 39 & 11 & \\
\hline & 02.07 .82 & 2048 & 512 & 57 & 131 & 20 & \\
\hline 15 & 08.02 .82 & 4096 & 256 & 62 & 156 & 86 & Glands \\
\hline & 13.04 .82 & 16384 & 2048 & 145 & 62 & 43 & \\
\hline
\end{tabular}




\section{SEQUENTIAL SPECIMENS}

A total of 36 samples from 15 patients were monitored in the dye test, indirect haemagglutination test, and enzyme immunoassay (IgG and IgM) systems for changes in titre during the stages of infection from which samples were available (Table 2). Titres in the four test systems did not always follow the same trend. Rising titres in sequential sera were detected by the IgG enzyme immunoassay system-for example, patient 3-but these did not necessarily reflect the changes seen with the dye test or indirect haemagglutination test.

The IgG result was classified as negative for one patient (11) and as uncertain positive for four further patients $(2,3,12$, and 13), although the titres in the dye test and indirect haemagglutination test were significantly raised. In each of these cases the IgM enzyme immunoassay result was positive. By measuring both IgG and IgM values these patients were readily detected as having significant antibody profiles. If the IgM test had been omitted, however, these cases would have been missed, unless a later specimen from the patient had been examined and a rising titre found.

When the pattern of results in both the IgG and IgM enzyme immunoassay systems was compared with the dye test and indirect haemagglutination test patterns a similar interpretation of the probable stage of infection was given for either set of tests in each of the 36 sera.

\section{Discussion}

This study has shown that the IgG and IgM enzyme immunoassay kits are of value in the detection of specific antibodies to $T$ gondii in human serum. Both classes of antibody should be tested for and measured if recent infections are not to be missed. The differences in serum dilution and incubation times between the two assays, however, prevents them being run simultaneously. The need to adsorb and confirm IgM values $\geqslant 20$ EIU means that two working days are required before the positive result can be reported. If the clinical evidence suggests a recent infection, a second specimen taken 10-14 days later should be tested to look for any change in titre.

The kits are relatively simple to handle and are supplied with adequate instructions, notes on the interpretation, and background information.

The cuvette blocks are convenient in use, particularly when the full system of incubating block and photometer are available. Use of the nine channel pipette allows the simultaneous addition of reagents to all nine wells, improving the standardisation of the assay. The test format should prove more useful in laboratories carrying out other biochemical assays with a colorimetric end point. These enzyme immunoassay tests are also available in a configuration compatible with the microtitre plate system, which are more likely to be acceptable to the microbiology laboratory committed to this format for assays already in use. These kits alleviate the need to use live $T$ gondii maintained by animal passage. In addition, greater standardisation and quality control should be feasible.

The expression of results in enzyme immunoassay units (EIU) relative to a standard serum, as recommended in the enzyme immunoassay kit protocol, proved useful and convenient. By this means minor variations in the absorbance values between runs are corrected for and values can be directly compared. In addition, different enzyme immunoassay tests can be directly compared by the interchange of standard sera. Use of both positive and negative control samples allows monitoring of the assays at both ends of the scale. The use of a continuous rather than a discrete scale of measurement should make feasible the application of various quality control techniques to these assays."

\section{WHO AND NATIONAL CONTROL SERUM STANDARDS}

Both the WHO (2000 IU/ampoule) and national control serum (1000 IU/ampoule) standards were produced for use in the dye test. While it may be useful to relate other immunoassays for $T$ gondii to these standards, account should be taken of the variations in antigen specificity as measured by the different test systems. The dye test uses live parasites to measure complement mediated cytotoxicity in vitro, with antibody specificity against membrane components playing an important part. The enzyme immunoassay uses an antigenic extract of the parasite, which may contain a variable amount of membrane components. The use of these different assay systems has shown a difference in the specificities of these two standard samples.

Calibration of the IgG enzyme immunoassay against the WHO standard has shown that the lowest detectable dye test value is $16 \mathrm{IU} / \mathrm{ml}(64)$, and the IgG enzyme immunoassay is less sensitive than the dye test. This is of relevance when determining the immune state of pregnant women and immunosuppressed patients. ${ }^{10}$ In epidemiological studies it can be of value to detect antibody down to a concentration of $11 \mathrm{IU} / \mathrm{ml}$. In recently acquired infections the detection rate is increased if specific IgM values are measured on all samples, even if the IgG enzyme immunoassay value is classed as negative ( $<10$ EIU). Five of the patients from whom 
sequential specimens were available fell into this group; subsequent samples showed rises in the IgG enzyme immunoassay titre, confirming a recent infection.

The sensitivity of the enzyme immunoassay system relative to the dye test increased from 88.2 to $92.4 \%$ when sera with either positive $\operatorname{IgG}$ or $\operatorname{IgM}$ results were included in the calculation, rather than considering only samples with positive IgG results. But this still left nine samples with positive dye test results not detected by the enzyme immunoassay system. The specificity of the enzyme immunoassay system was good $(94.7 \%)$ with $18 / 19$ dye test negative samples negative in the IgG enzyme immunoassay. The remaining serum gave only a weak positive result of 12 EIU and the full serological profile and clinical details showed evidence of a past infection in this patient.

In our hands the indirect haemagglutination test provides useful data on the probable stage of a $T$ gondii infection when used in conjuction with the dye test and a suitable IgM assay. It is not suitable to use alone, however, as it can produce titres which are difficult to relate to a specific infection. In the current study the overall agreement of the IgG enzyme immunoassay with the indirect haemagglutination test is slightly better than that found between the IgG enzyme immunoassay and dye test, although the indirect haemagglutination test gave nine more positive results than the dye test.

The detection of specific antibody of the IgM class is of value in determining the probable stage of a $T$ gondii infection. ${ }^{4}$ The indirect immunofluorescence test has been used for this purpose, but the test is subjective to read and interpret. In addition, false negative results due to the saturation of binding sites by excess specific IgG and false positive results due to rheumatoid and antinuclear factors can occur unless the serum is fractionated before testing.?

In the present study the percentage of samples positive in the indirect immunofluorescence test for IgM rose from $51.8 \%$ with whole sera to $70 \%$ with fractionated sera. This may be due partly to the subjective nature of the test in that fractionation removes debris and consequent background fluorescence, so that the test antigen appears to show a stronger reaction in comparison with the whole serum. The IgM enzyme immunoassay produced only $32.7 \%$ positive samples using the prescribed cut off values, although a further $17.3 \%$ of the sera had doubtful positive results. Taking the two groups together $(50 \%)$ this is close to the number of sera regarded as positive in the whole serum indirect immunofluorescence test for IgM. Direct comparison between the indirect immunofluorescence test and IgM enzyme immunoassay was, however, of limited value. It is probably more important to gain further experience in the use of the IgM enzyme immunoassay on patients' specimens and evaluating the results in relation to the clinical findings. Despite the useful information that has been obtained by use of the indirect immunofluorescence test for IgM, there is a definite need for a more robust test to detect specific IgM directed against $T$ gondii, not subject to the problems of the indirect immunofluorescence test for IgM. The IgM enzyme immunoassay seems to be a viable alternative.

The detection of any specific IgM in the neonatal circulation is of importance in the diagnosis of congenital toxoplasmosis, but the concentration of antibody detected by the IgM enzyme immunoassay and its importance needs to be determined by both clinical and laboratory experience.

One patient in this study, investigated for swollen glands and a viral like illness of three months' duration, gave an IgM enzyme immunoassay of $53 \mathrm{EIU}$ although the IgG enzyme immunoassay was only 4 EIU. The dye test was 8 , the indirect immunofluorescence test for IgM $\geqslant 40$ on both the whole and fractionated serum, and the indirect haemagglutination test 512. Although the indirect haemagglutination test result may be discounted as spurious, the positive IgM results indicate the need for investigation of further specimens from this patient, illustrating the value of a specific IgM assay and the need to treat a single IgG enzyme immunoassay result with caution.

No false positive IgM enzyme immunoassay results were obtained for 30 sera which were negative for antibodies to $T$ gondii when examined by the dye test, indirect haemagglutination test, and indirect immunofluorescence test IgM.

We are grateful to Labsystems Oy for making the enzyme immunoassay kits available and to the PHLS technical staff who contributed to this work.

\section{References}

Hunter D, Chadwick P, Balfour AH, Bridges JB. Examination of ovine foetal fluid for antibodies to Toxoplasma gondii by the dye test and an indirect immunofluorescence test for specific IgM. Br Vet J 1982;138:29-33.

${ }^{2}$ Fleck DG, Kwantes W. The laboratory diagnosis of toxoplasmosis. Public Health Service Monograph series no 13. HMSO: London, 1980.

${ }^{3}$ Balfour AH, Fleck DG, Hughes HPA, Sharp D. Comparative study of three tests (dye test, indirect haemagglutination test, latex agglutination test) for the detection of antibodies to Toxoplasma gondii in human sera.J Clin Pathol 1982;35:228-32.

${ }^{4}$ Karim KA, Ludlam GB. The relationship and significance of antibody titres as determined by various serological methods in glandular and ocular toxoplasmosis. J Clin Pathol 1975;28:42-9. 
${ }^{5}$ Pyndiah N, Krech U, Price P, Wilhelm J. Simplified chromatographic separation of immunoglobulin $M$ from $G$ and its application to toxoplasma indirect immunofluorescence.J Clin Microbiol 1979;9:170-4.

- Violand SA, Mitchell TG, Kleeman KT. Comparison of an enzyme-linked immunoassay and a quantitative indirect fluorescent-antibody test with the conventional indirect fluorescent-antibody test for detecting antibodies to Toxoplasma gondii. J Clin Microbiol 1982;16:341-4.

${ }^{7}$ Hunter D, Chadwick P, Balfour AH, Bridges JB. An assessment of a commercially available haemagglutination test for detecting toxoplasma antibodies in ovine sera. $\mathrm{Br} \mathrm{Vet} J$ 1980; 136:339-42.
${ }^{8}$ Souvaniemi O, Jarnefelt J. Discrete multi-channel analysis systems. International Laboratory 1982;April:48-60.

${ }^{y}$ Batty I. Standards and quality control in clinical immunology. In: Thompson RA, ed. Techniques in clinical immunology. Oxford: Blackwell, 1977.

${ }^{10}$ McGregor CGA, Fleck DG, Nagington J, Stovin PGI, CoryPearce R, English TAH. Disseminated toxoplasmosis in cardiac transplantation. J Clin Pathol 1984;37:74-77.

Request for reprints to: Dr AH Balfour, Public Health Laboratory, Bridle Path, York Road, Leeds LS15 7TR, England. 